\title{
Steve Murphy, Marges du premier Verlaine
}

\author{
Ida Merello
}

\section{(2) OpenEdition}

\section{Journals}

\section{Edizione digitale}

URL: https://journals.openedition.org/studifrancesi/41053

DOI: 10.4000/studifrancesi.41053

ISSN: 2421-5856

\section{Editore}

Rosenberg \& Sellier

\section{Edizione cartacea}

Data di pubblicazione: 1 juillet 2004

Paginazione: 216

ISSN: 0039-2944

\section{Notizia bibliografica digitale}

Ida Merello, «Steve Murphy, Marges du premier Verlaine», Studi Francesi [Online], 142 (XLVIII | I) | 2004 online dal 30 novembre 2015, consultato il 09 septembre 2021. URL: http://journals.openedition.org/ studifrancesi/41053 ; DOI: https://doi.org/10.4000/studifrancesi.41053

\section{Questo documento è stato generato automaticamente il 9 septembre 2021.}

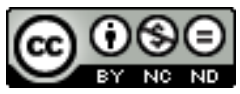

Studi Francesi è distribuita con Licenza Creative Commons Attribuzione - Non commerciale - Non opere derivate 4.0 Internazionale. 


\title{
Steve Murphy, Marges du premier Verlaine
}

\author{
Ida Merello
}

\section{NOTIZIA}

STEVE MURPHY, Marges du premier Verlaine, Paris, Champion 2003, 422 p.

1 L 'A. ripercorre la carriera poetica di Verlaine, fin dalla prima prova nel 1858, intitolata La Mort e inviata a Victor Hugo, individuando l'influenza già esercitata sul giovanissimo poeta dai Châtiments e le Contemplations. Prosegue quindi il suo lavoro di accurata disamina dei manoscritti, concedendo ampio spazio alla prima stesura della poesia dedicata a Monsieur Prudhomme, scritta un anno prima (1862) della pubblicazione, e segnala alcune varianti semantiche di considerevole importanza. Quel che preme all'A. è portare alla luce il processo di costruzione della personalità poetica attraverso la fitta rete delle influenze. Se Monsieur Prudhomme è fondamentale per il confronto con Hugo, le Liturgies intimes lo sono per quello con Baudelaire. L'A. si interroga anche sulle possibili datazioni dei vari manoscritti, con acuta disamina dei testi. In un secondo momento l'A. fa il punto sulla natura del Parnasse e del parnassianesimo, ribadendo la sua qualità di nebulosa e non di scuola, e mostrando come, all'interno di questa, Verlaine utilizzi Baudelaire per smarcarsi dal gruppo gravitante attorno a Leconte de Lisle. Si sofferma quindi sulla nozione di marginalità poetica, individuandola nella vena di poesia conviviale e vicina alla chanson, che, coltivata da Verlaine, era già stata praticata da Hugo e Musset, ma anche da Cros e dallo stesso Mallarmé. Questa forma, che l'A. definisce parapoésie, è ampiamente praticata da Verlaine, dove appare non solo strettamente legata alla rappresentazione della sessualità, ma anche a preoccupazioni di ordine sociale e politico. Ogni affermazione critica è sorretta e confortata da una minuta analisi testuale. 